DOI: https://doi.org/10.47405/mjssh.v6i9.1030

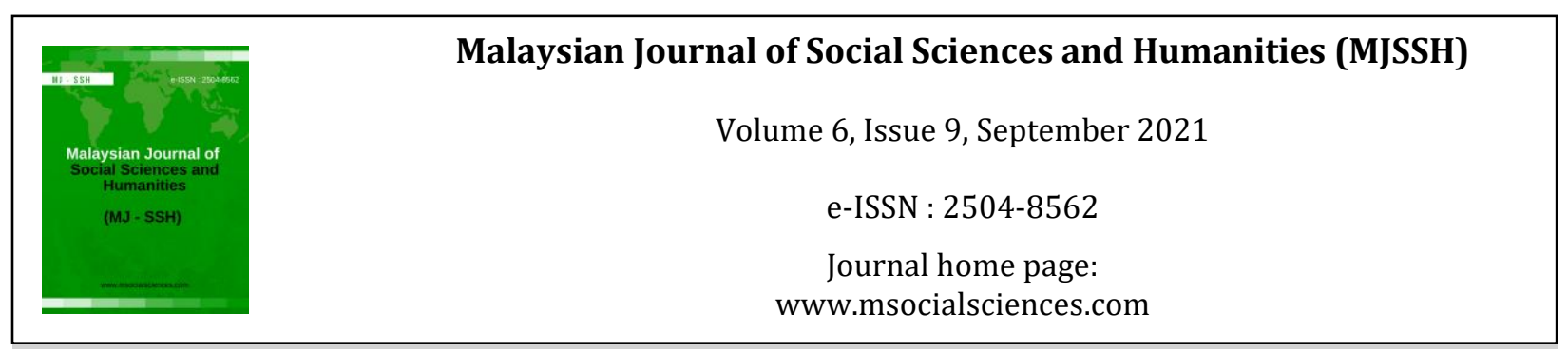

\title{
Reaching Happiness beyond Emancipation: A Study on the Human-Centric Role of Linde in $A$ Doll's House by Henrik Ibsen
}

\author{
Md. Abu Saleh Nizam Uddin', Farhana Yasmin'1 \\ 1Department of English Language and Literature, Faculty of Arts and Humanities, \\ International Islamic University Chittagong (IIUC), Bangladesh \\ Correspondence: Md. Abu Saleh Nizam Uddin (nizam_cu13@iiuc.ac.bd)
}

\begin{abstract}
Henrik Ibsen's drama $A$ Doll's House portrays the late $19^{\text {th }}$ century Norway where protagonist Nora and her eventual manifestation of Feminism are almost all the time at the centre of critical attention. But Mrs. Kristina Linde is also a character of magnanimous stature with her enthusiastic sense of belonging and heart-felt services to family and society. In this manner, the human-centric role provides Linde with satisfaction that amounts to happiness, taking her ways ahead of emancipation in a world where women's emancipation from sufferings is still an unresolved issue. Notably, Linde's humancentric role gains authenticity as a true means of women's emancipation by reflecting higher knowledge which is essential for any human affair to be true and real. Thus, this paper aims at exploring how Mrs. Kristina Linde in A Doll's House by Henrik Ibsen, being in her family and society and playing vital roles accordingly, derives happiness proving the truth that all women can be humancentric in family and society, and can have happiness going far ahead of emancipation changing the global scenario of women's misery. The methodology of thematic analysis was followed in this research. The research may contribute in propounding human-centric family and social life as the proper means of women's emancipation.
\end{abstract}

Keywords: happiness, human-centricity, Linde, feminism, unity of knowledge

\section{Introduction}

When the drama A Doll's House (1879) by Henrik Ibsen (1828-1906) is set under critical lens, its protagonist Nora Helmer and her ultimate show of feminist spirit are focalized by critics in myriads of research works. But Nora's friend Mrs. Kristina Linde deserves critical attention too. Interestingly, Linde, in humanity, proves to be greater than Nora, the protagonist. Whenever in the drama we see Linde in action for the first time, we see the action is meant for others. Most importantly, as she remembers her past, we again see she was struggling with every bit of her capacity to help others. This is how her past and present consist of love and care for her family and society. In addition to her instinctive goodness, the positive social dynamics inherent in her traditional moral system and religion that provides one with "a positive evaluation of one's life" are sure to have conscious and subconscious impact upon her (Villani et al., 2019, "Association between", para. 1). She believes the satisfaction of soul which can be derived from interdependency of "interpersonal harmony, quiescence and ordinariness" and complementarity with all in family and society irrespective of gender or any other identity, cannot be provided by anything else (Hitokoto \& Uchida, 2018, Abstract). By being 
concerned with her inner urge, Linde sustains essential properties of heart in nurturing love, affection, sympathy, kindness, longing, gratitude, onuragh (a Bangla word with no English parallel expressing a tender feeling between anger and love happily nurtured by a romantic couple), honor, awe etc. Linde represents beauty of life, and when "Beauty is truth, truth beauty", the truth remaining innate in the beauty of her life's approach can be endorsed by knowledge. This human-centricity is her soul's satisfaction transforming into soul-comforting happiness.

Not only numerous researches on Nora, but also the failure of Feminism itself makes critiquing on Linde inevitable. If the failure of Feminism is concerned, what UN Secretary-General António Guterres views may be concentrated on. He posits Mary Wollstonecraft "is often seen as the mother of western feminism"; but here it is perhaps not necessary to signify Feminism with "western" because its very inception and growth that followed were the contributions of the west. Afterwards, Feminism did and still does assume various regional or religious or political or cultural entities (2020, para.11). So, it is perhaps arguable to mention "western feminism" indicating that there is eastern or non-western Feminism independently originating and flourishing in those regions. So, from Guterres's view that Wollstonecrafts "is often seen as the mother of western feminism", it may be construed that 1792, the publication year of the feminist text $A$ Vindication of the Rights of Women by Wollstonecraft, is the unofficial starting point of Feminism. If the time from 1792 till today in 2021 is counted, it is a period of two hundred twenty nine years which is actually the age of Feminism. But has Feminism been able to solve the crisis of women? This question many conscious minds are asking now-a-days. Guterres admits "the state of women's rights remains dire" (2020, para. 15). One of the key reasons behind this failure is staunch contention with family life which Feminism directly or indirectly expresses through misandry. Acknowledging the misandry, a viewpoint states, “... the more I have spoken about feminism the more I have realized that fighting for women's rights has too often become synonymous with man-hating" (Watson, 2014, para. 4). But has this appeal to stop "man-hating" been able to create any impact? If we search, we see no impact. This is why, a recent feminist voice, even when expressing concern for children including women, does not forget to omit men. It states the surges of Covid-19 pandemic "were failing women and children"; thus it excludes millions of men across the globe, who face a harrowing scenario emanating from their income-related crisis (Brooks, 2020, para. 6).

To Samuel Johnson, Shakespeare is "the poet of nature; the poet that holds up to his readers a faithful mirrour of manners and of life" because "they are the genuine progeny of common humanity, such as the world will always supply, and observation will always find" (n.d., para. 8). To Johnson, "[Shakespeare's] persons act and speak by the influence of those general passions and principles by which all minds are agitated, and the whole system of life is continued in motion" (n.d., para. 8). So, Shakespeare's realization is that the "general passions and principles" of humans are common and constant irrespective of time and space. Thus when the inner self of humans are common and constant, their outer or physical dimensions are in an ever-changing process in accordance with the changing world. If Feminism had any goal to rediscover women's inner self, and thus knew that the inner self has its inseparable law of remaining in harmony with others in family and society which human history and nature prove, Feminism could be confident and could accordingly give an immutable solution to women's misery. But as only the changing issues related to the physical self of women are focused by Feminism, it has to remain in a continuous change to be accommodated. Thus we see radical feminism, moderate feminism, liberal feminism, first wave feminism, second wave feminism, third wave feminism, fourth wave feminism, capitalist feminism, Marxist feminism, Islamic feminism and the like. Despite reaching age two hundred twenty nine, Feminism is yet to come to a resolution about how actually it will be. So, when it will come to a constant resolution paradoxically becomes an anxiety heavier than women's misery itself.

Therefore, in this world scenario, recuperation of family-, society- and human-centricity may prove to be the proper means to bring for women not only emancipation but also happiness. Also, this means, by imbibing deeper knowledge, provides authentication to its success. In line with this observation, we find the human-centric role of Linde in A Doll's House. 


\section{Literature Review}

When the research on Ibsen's $A$ Doll's House is studied and review of literature is done, we find almost all research focuses are set supporting the feminist dimension of Nora. One research compares Nora with the female characters of some short stories by Rabindranath Tagore (read Rabindranath Thakur). The researcher of the research tries to explore similarity between the two authors in emphasizing women's assertion of their individuality in an antagonistic environment. In this feminist research, researcher writes, "Their freedom can be ensured only when they are conscious of their subjectivity" (Chowdhury, 2010, p.107). Another research eulogizes Nora's decision of leaving her family, identifying it as bold and courageous. The researcher opines that Torvald could allow Nora feel some self-esteem like him by permitting her to earn. The research writes, "If Torvald has given equal rights and opportunities to Nora to support the earning of the household, the sudden evocation of selfrespect may not have energized Nora to leave him" (Azam, 2014, p.14). In another research, researchers rely on Beauvoire's concept woman as "the other". They express their opinion that marital system itself is flawed. Individuality and freedom of women are snatched by masculine society while humanity and individuality are of most importance. About Nora's decision to leave her family, the researchers write, "What the audiences saw was that once Nora was awakened, the kind of life Torvald imagines for her was a sort of death for Nora" (Ghafourinia \& Jamili, 2014, p.428). To them, Nora reaches the real maturity, and what has been done by her is actually her own rights. Also, critics opine Torvald's care for "public moral concern" eventually neglects women, and thus, Nora is also neglected for which she is "in search of true individuality-which adds universality to the theme" of the drama (Karim, Fathema \& Hakim, 2015, p. 22). Yet another research opines Nora has successfully fought against oppressive patriarchy. It write, "In fact, she goes through a good number of struggles and brings forth her own narratives so that she can withstand the patriarchal discrimination and oppression against women and live an independent life" (Islam \& Suchi, 2020, p.126).

The researchers on $A$ Doll's House do their critiques from feminist perspective focusing and supporting the character of Nora. But the human-centric viewpoint of good, holistic and harmonious life in family and society differing with the feminist paradigms, which is manifested in the text by Mrs. Kristina Linde, is also significant. Her way of life makes her satisfied and happy, and that her life is true can be authenticated by deeper knowledge. Thus, Linde's human-centric life may be a means of women's emancipation in the world. There has been hardly any research in this area. This research gap our present research addresses.

\section{Methods}

For the present research, we preferred the methodology of thematic analysis. When readers have their analytical selves of morality, humanity and religiousness, how much it reflects on literary theorists' attempts of theorizing literature is a matter of essential discussion. Ward validly asks, "If the reader is an agent whose choices have moral import and whose conduct as reader is subject to the categories of ethical discourse, what ontological status are such theorists ascribing to literature in the ultimate scheme of things?" (1990, p. 2). Ward's opinion as expressed in her question validated the requirement of analyzing Linde's humancentric role from the perspectives of now-neglected yet ever-essential codes of humanity. Being inspired by Ward, we also relied on the theory of Religious Humanism for its suitability with our research concentration. The exponents of Religious Humanism are religious scholars Erasmus, Blaise Pascal and Jacques Maritain. On Religious Humanism, New World Encyclopedia writes,

Religious humanism embraces some form of theism, deism, or supernaturalism, without necessarily being allied with organized religion. The existence of God or the divine, and the relationship between God and human beings is seen as an essential aspect of human character, and each individual is endowed with unique value through this relationship. Humanism within organized religion can refer to the appreciation of human qualities as an expression of God, or to a movement to acknowledge common humanity and to serve the needs of the human community. ("Secular and Religious Humanism", para. 2) 
So, the theory accommodates all religious beliefs including Islam. Thus facilitated, humanistic role of Linde was examined from episteme related to men's instinctive goodness and the revelations of Christianity. Then at last, envisaging exquisite beauty and high dignity in Linde's family- and societycentric role, as we delved deep into it for truth and knowledge, we ascended a very high level of epistemology that required us to include Newman's Liberal Knowledge which is his finding inspired by Christianity. Then the highest echelon of epistemology included Tawhidi methodology, the Islamic knowledge system discovered by Choudhury. Thus the ideas of holistic and unified knowledge propounded by Christianity and Islam helped to construct our critical purview.

This is how the thematic analysis was done in this qualitative research. To accomplish this research, books, research articles and speech were collected in keeping with the focus of the research. Then data were carefully analyzed to reach our finding and sum up a conclusion.

\section{Results and Discussion}

\section{Linde's Human-Centric Roles in Family and Society in A Doll's House}

\section{As a Daughter and a Sister}

In the drama A Doll's House, readers are not told anything about Linde's father. Perhaps because of his death, we see her as a fatherless lady. However, she was the eldest of three children that her mother had. From Linde's account to her friend Nora, we come to know about the tragic variegatedness of her life. She had her sick mother and two minor brothers to look after. Also, she was in love with a man Nils Krogstad by name, which readers are able to know later in the drama. However, when in the pressing circumstances of her life, Linde was forced to marry a business man sacrificing her love affair. She took the decision for the sake of her severely sick mother and two minor brothers. To Nora, Linde says, "My mother was still alive; she was bedridden and helpless, and I had my two younger brothers to look after - I didn't feel I could refuse his offer" (Ibsen, 1965, p. 13). But after some days her husband died keeping no money or leaving no child with Linde. Then Linde's hardship for the survival of her family turned more acute. To Nora, she says, "Well, I just had to struggle along - I ran a little shop, then a small school, and anything else I could turn my hand to. These last three years I never seem to have stopped working" (Ibsen, 1965, p. 13).

Though with much hardship, she managed to take care of her mother and the two brothers. Here lies the reason of her pride and satisfaction. Even she has no regret for marrying a man being pressed by the circumstances. She says to Nora, “... but of course I'm proud - and glad - to know that I was able to make Mother's last days a little easier" (Ibsen, 1965, p. 15). Linde did not only live with her family, but also took proper care of her family members to the best of her ability keeping cordial relationship with them. So, now her life has a satisfaction and happiness because the truth is "that better family functioning is strongly associated with happier people and greater life satisfaction" (Botha \& Booysen, 2013, p.180).

When Linde comes to Nora, she is completely alone as her mother is already dead and her brothers are grown up men who need no help from her any more. When nobody is to be taken care of, Nora considers it as a relief for Linde. But Linde disagrees. She says after her mother's death and brothers' involvements in their own life, there is only intense nothingness within her. She says for whom she will work and live if it is not for her family. By doing a job, she will definitely try to earn her livelihood but with no less importance it will keep her mind engaged in work so that the mind cannot pay attention on the nothingness of her life. She says,

No - just unspeakably empty - I have no one to live for any more. [...] That's why I couldn't bear to stay in that little backwater any longer. It must be easier to find some sort of work here that'll keep me busy and take my mind off things. (Ibsen, 1965, p. 13) 


\section{As a Friend}

When the two friends-Nora and Linde-are together after many years, Linde has real concern to know about Nora's difficulties or challenges of life. Linde, as a good listener, participates in a conversation with Nora because Nora has the tendency to speak more which is happily accepted by Linde. When for Christmas Nora feels she has to put on an old dress after doing some mending, Linde herself does the mending and satisfactorily says, "There - I don't think there is anything else that wants mending. Let's try it on" (Ibsen, 1965, 56). At one stage, Nora starts sharing her secret - how her husband fell sick, how it became severe, how taking loan was the only option for managing the money for the treatment and how she has kept the loan affair hidden from her husband so far. Hearing everything, Linde tries to give ideas to Nora, so that the latter can overcome the difficult situation. She suggests Nora to disclose the fact to her husband and also tells her not to worry. She wants that both Nora and her husband should face the fact to sort out and remove each misunderstanding. Linde goes to Krogstad to stop his blackmailing upon Nora. As Krogstad works in an office where Nora's husband Torvald is his superior, Krogstad, after committing corruption, has been blackmailing Nora to save his job through her. The ground on which Krogstad tries to blackmail Nora is that Nora copied her father's signature to make him the guarantor of a loan which she was bound to take to bear the expenditure of critically sick Torvald. During that time Nora's father was also in his death bed. Realizing that taking signature from her dying father would be inhuman, and being in a tremendous mental pressure, Nora copied her father's sign without putting the date. By this time Nora's father died. Meanwhile, below that signature which was that of Nora's father copied by her, Krogstad, who was involved in managing the loan, mentions a date later than the day of the death of Nora's father. Thus, Krogstad ensures the impression of forgery on a seemingly genuine signature. Then he threatens Nora saying that he will disclose to her husband about the signature forgery if she, by using her influence on her husband, does not help to save his position in the office. But helpful Linde continues her effort to change the mind of Krogstad.

However, there is another scene where we find Linde's concern for her friend Nora. After getting introduced with Doctor Rank, Linde later advises Nora not to encourage him for coming to her home. Linde also tells her to stop talking with him. Though Doctor Rank is not a bad person, Linde doubts him as she is worried about her friend. Linde says, "you ought to stop all this with Dr Rank" (Ibsen, 1965, p. 40). Afterwards, we come to know that Linde has been right in cautioning Nora about Doctor Rank because old and sickly Rank quite peculiarly considers Nora's innocent and frank behavior as something romantic.

Towards the end of the play, when Nora tells Linde she will rather leave her family once Torvald is at the verge of knowing about her forgery, caring Linde simply gives an outcry "Nora, Nora, you must be out of your senses!" (Ibsen, 1965, p. 57). Though Linde cannot stop Torvald from seeing the letter of Krogstad which reveals Nora's signature forgery though it was unintended, she does succeed in convincing Krogstad to send the actual bond to Torvald ensuring that no more legal threat remains for Nora. Still we see Nora leaving her family. But Linden fulfils the commitment of friendship.

\section{As a True Woman}

An empirical study was done in the USA to improve the health condition of the school-going children by removing their obesity problem. As health condition is also linked with overall happiness of a man and good family life is believed to contribute to that happiness, the study, besides other forms of research, took the interviews of some English- and Spanish-speaking parents to know about their happiness in connection with their family. The parents rather expressed their exuberance while saying that happiness of their family was the reason of their own happiness. The study mentions, 'When asked to identify the factors most important in determining how happy they feel, parents agreed that one of the main determinants was "family happiness - if my family is happy, then I am happy" (Eck et al., 2019 , p.3)

When the study visualizes the importance of family life for a person in becoming happy, the truth is properly imbibed by Linde of $A$ Doll's House. So, she was actively spending her family life taking care of her sick mother and minor brothers. After her mother's death and brothers' self-dependence, she 
again wants to be involved with family through marriage. She seems to realize "Far from oppressing women, [marriage] offers a safe foundation for a full life" (Charen, 2018, para. 12). When Linde, by virtue of a happy chance, meets again with Krogstad who she was in love with, Krogstad is already a widower with several children. Yet Linde wants to marry him. So fervent is her feeling when Linde says to Krogstad that she needs someone to take care of, a baby to give birth to, some children to be the mother of and warm relationships to be involved in. She says, "I need someone to be a mother to, and your children need a mother. You and I need each other. I have faith in you - the real you - Nils, with you I could dare anything" (Ibsen, 1965, p. 66).

Here what is clear is Linde's belief in healthy human relationships where understanding, sharing and caring give immense pleasure. Besides, when Linde is presumably past her young age and her physical beauty is in a declining stage, her virtue is what attracts Krogstad. If, on the other hand, outwardly corrupted Krogstad was not having dormant virtue inside him, Linde would not feel attracted in him again. About her knowledge of Krogstad's dormant goodness, she confirms by saying "I know only too well how far despair can drive a man like you" (Ibsen, 1965, p. 66).

From the beginning of the drama, we find Krogstad as a morally afflicted person who blackmails Nora for saving his position in the bank. But Linde changes the scenario. She convinces Krogstad not to reveal the secret of Nora to her husband. But it has been too late though Krogstad does send Torvald the actual bond containing Nora's signature. As Linde is human-centric and selfless, she can positively make use of the experience of her life, and thus, she knows how to manage and guide someone to doing good to others.

\section{Key Factors to Contribute to Linde's Vitality and Integrity}

When we see Linde cordially involved with her family and society, it is clear to us that to her, the meaning of labor is service to others, not material gain like money. So, she is humanity-centric, not materialistic. She does not expose herself to Western Materialist Rationalization. Notably, Rationalization means "the act, process, or result of rationalizing : a way of describing, interpreting, or explaining something (such as bad behavior) that makes it seem proper, more attractive, etc" (Merriam-Webstar). Clearly, by being amoral and anti-human, Rationalization is materialistic. Elmessiri opines that because of Materialist Rationalization, meaning of labor has changed from being humanistic to materialistic, and as a result, the labor which a woman gives at home is not deemed labor any more. Elmessiri writes,

Materialist rationalization has been so pervasive and comprehensive, in all walks of public and private life, that human labor has been narrowly defined as work performed in the public sphere or related to it in one way or another, and for which a person receives a certain monetary remuneration. (2004, p. 17)

But confident Linde remains committed to her service to others, and to readers, her dignity reaches a conspicuous height. To talk about which tradition Norwegian or Western Linde in the context of $A$ Doll's House hails from, we see Ibsen wants us to look at first at the religious atmosphere built up by him just when the drama opens. The time is shown as Christmas Eve, and Nora brings home a Christmas tree. She enthusiastically wants to hide it from her children to unveil it later as a surprise for them. Nora tells her maid Helena, "Hide the Christmas tree properly, Helena." (Ibsen, 1965, p. 1). So, the religious atmosphere at the very outset draws readers' attention and with that religious atmosphere we can draw the link of Linde's vital role in family and society because of the similarity religion has with familial and social life. As the drama shows the late $19^{\text {th }}$ century Norway, the social context of the drama is materialistic by nature reflecting the then society and this we can say because "these countries [the Scandinavian countries including Norway] had been ultra-capitalist from around 1870 to the 1960 s" while capitalism is materialistic by being capital-centric (Sabhlok, 2018, para. 6). But when Linde stands apart with her human-centricity, its origin can only be her instinctive goodness and Christianity. We bring Christianity here because The Holy Bible gives supreme importance to marriage, family and society which is explicit in the Biblical definition of the vital issues. The Holy Bible states that marriage will take place between a man and a woman, and they will have children who are the 
Blessings from the Almighty. Thus family will be built up. Kostenberger, in his language, narrates the teachings of The Holy Bible:

The Bible defines "family" in a narrow sense as the union of one man and one woman in matrimony which is normally blessed with one or several natural or adopted children. In a broad sense, this family also includes any other persons related by blood (the extended family). (2011, p. 2)

After marriage, the necessity of having children, becoming family and making use of things in nature that are given by the God are stated in the holy text. Kostenberger quotes what Genesis professes stating "...be fruitful and multiply and fill the earth and subdue it and have dominion" and explains that the command over Adam and Eve is applicable to all mankind (2011, p. 2). Linde manifests the teachings of The Holy Bible.

\section{Knowledge that Endorses the Appropriateness of Linde's Human-Centric Roles}

If Linde's enthusiastic involvements and happy accomplishments in family and society as expressed in A Doll's House are the proper means of women's emancipation, how much or what type of knowledge supports her means may be examined.

Here quite relevant is the inter-connectedness of knowledge system which Newman in The Idea of University calls "'Liberal" knowledge of "freedom, equitableness, calmness, moderation, and wisdom" (2007, para. 4). Newman views that no study of any branch of knowledge can go forward alone because it has connection with other branches (2007). So, knowledge of one branch must maintain unity and harmony with other branches of knowledge if it wants to be successful theoretically and practically. Mentioning God as the reason behind the organized world of knowledge, Newman states, "... all branches of knowledge are connected together, because the subject-matter of knowledge is intimately united in itself, as being the acts and the work of the Creator" (2007, para. 2). Now we can say if objects and creations are the manifestation of the unity and harmony-prone knowledge, men are the ones to discover and implement that system of knowledge in the world. Thus, men can unite with the knowledge and world systems, which will make them successful and happy. Likewise, in $A$ Doll's House, Linde materializes unity and harmony by being in family and society, and becomes happy by going far ahead of emancipation. Linde's approach, being holistic and human-centric, unlike Feminism's isolatory, materialistic and self-centric ones, conform to Newman's "Liberal" knowledge.

After going through Newman's "“Liberal"' knowledge which indicates connection, harmony and unity among various fields of knowledge which is authored by the God, one feels more urge to realize the presence of a Supreme Being behind the unique arrangement in human life, earth and cosmology (2007, para. 4). The Supreme Being is the God of monotheist beliefs. In Islam He is Allah. Relying on this observation, scholar Choudhury comes up with the inter-disciplinary approach to knowledge called Tawhidi Methodological Worldview (tawhid - belief in One God, Allah). Choudhury writes,

God is the fullness of knowledge that is embodied in the monotheistic law as the primal ontology, meaning theory of being and existence. The world-system ('alaminn) is described and is spanned by the signs of monotheistic unity of knowledge in the good things of life and its opposite in the bad things of life by participatory association and differentiation, respectively. $(2018$, p.268)

Choudhury means that Supreme Knowledge remains only in the God. The Supreme Knowledge is embodied in the laws which the God has ascribed on every single object and creation of the world. The laws are known as the "theory of being and existence" to be seen in any object or creation. Then the God shapes the disseminated knowledge into a world system based on "unity of knowledge". A good life will function according to that unity in association with others but a bad life will be self-centric, and break away from association. That good life is actually the life of Linde in A Doll's House with her harmonizing and unifying approach to family and society. And the bad life is the life of isolation, separation and self-centricity. Thus, emancipation being an issue of bygone time, Linde lives in a world 
of happiness by conforming to Choudhury's "unity of knowledge", the structure of knowledge as designed by the God.

\section{Conclusion}

Clearly, Mrs. Kristina Linde in A Doll's House by Henrik Ibsen proves herself to be the most attractive character of the drama with her self-less human qualities like love, affection, courage, wisdom, endurance, benevolence and optimism. Her roles as a daughter, a sister, a friend, and a woman vindicate her as someone whose human-centricity is expressed through her unbreakable and cordial tie with family and society. Her role is beautiful, dignified, and authenticated by higher truth and knowledge. She is satisfied and happy while her emancipation is an irrelevant issue to her. This is how, in $A$ Doll's House, the human-centric life which Linde represents with her cordial and active involvements with family and society is the proper means for women to gain not only emancipation but also happiness in a world of women's misery. Thus human-centricity shines. To implement the finding of this research related to women's emancipation and happiness, honest men and women who are in favor of holistic humanity through proper functioning of family and society can give effort to build a value-, family-, society-, humanity- and religion-centric infrastructures of politics, education, economy and culture.

\section{References}

Azam, A. (2014). Nora Helmer in Ibsen's A Doll's House: A Feminist concern in English Literature. Journal of English language and Literature, 1(1), 13-17 DOI: 10.17722/jell.v1i1.7

Botha, F. \& Booysen, F. (2013). Family Functioning and Life Satisfaction and Happiness in South African Households. Social Indicators Research 119(1). 163-182. DOI: 10.1007/s11205-013$\underline{0485-6}$

Brooks, K. (2020, Decmeber 23). Feminism Has Failed Women. The New York Times. https://www. nytimes.com /2020/12/23/opinion/coronavirus-women-feminism.html

Charen, M. (2018, July 7). Feminism has destabilized the American family. New York Post. https://nypost.com/2018/07/07/feminism-has-destabilized-the-american-family/

Choudhury, M. A. (2018). Tawhidi Islamic economics in reference to the methodology arising from the Qur' an and the Sunnah. Tawhidi Islamic Economics, 263-276.

Chowdhury, M. S. I. (Fall 2011). The Restoration of Feminist Subjectivity in Henrik Ibsen and Rabindranath Tagore. Crossings: ULAB Journal of English Studies. 3(1), 99-108.

Eck, K., Delaney, C. L., Olfert, M., Shelnutt, K., \& Byrd-Bredbenner, C. (2019). "If my family is happy, then I am happy": Quality-of-life determinants of parents of school-age children. SAGE Open Medicine, 7(2). DOI: 10.1117/2050312119828535

Elmessiri, A. M. (2004). Feminism versus Women's Liberation Movement, UASR Inc.

Ghafourinia, F., \& Leila B. J. (2014). The Women's Right in Henrik Ibsen's A Doll's House. JNAS Journal, 3(4), 424-429. http://jnasci.org/wp-content/uploads/2014/04/424-429.pdf

Guterres, A. (2020, February 27). Twenty-first Century Must Be Century of Women's Equality, Secretary-General Says in Remarks at The New School, United Nations: Meeting Coverage and Press Release. https://www.un.org/press/en/2020/sgsm19986.doc.htm

Hitokoto, H, \& Uchida, Y. (2018). Interdependent Happiness: Progress and Implications. [Abstract]. Close Relationships and Happiness across Cultures. DOI: 10.1007/978-3-319-89663-2_2

Ibsen, H. (1965). A Doll's House. Penguin Books India, 1-116.

Islam, A. B. M. S., \& Shuchi, I. J. (2020). Nora's Metamorphosis from a Doll child into a reasonable human being :Reading Henrik Ibsen's A Doll's House. Rainbow: Journal of Literature, $\begin{array}{llll}\text { Linguistics and Cultural } \quad \text { Studies, } & \text { 125-136. }\end{array}$ https://journal.unnes.ac.id/sju/index.php/rainbow

Johnson, S. (n.d.). Preface to Shakespeare. The Project Gutenberg $e$ - book Series, http://lcwu.edu.pk/ocd/cfiles/English/Eng/Maj/PrefacetoShakespeare.pdf

Karim, S. M., Fathema, F., \& Hakim, A. (2015). Man-woman relationship in Henrik Ibsen's A Doll's House. International Journal of Social Sciences, Arts \& Humanities, 3(1), 21-26. 
Kostenberger, A. J. (2011). The Bible's Teaching on Marriage and Family. Family Research Council, Washington.

Merriam-Webster. (n.d.). Rationalization. In Merriam-Webster Dictionary. Retrieved June 27, 2021, from https://www.merriam-webster.com/dictionary/rationalization

Newman, J. H. (2007). Discourse 5: Knowledge its Own End. The Idea of University. The National Institute for Newman Sudies. https://www.newmanreader.org/works/idea/discourse 5.html

New World Encyclopedia. (n.d.).Humanism .https://www.newworldencyclopedia.org/entry/humanism Sabhlok, S. (2018, December 27,). The failed socialist experiment of capitalist Scandinavian countries. The Times of India. https://timesofindia.indiatimes.com/blogs/seeing-the-invisible/the-failed-socialistexperiment-of-capitalist-scandinavian-countries/

Villani, D., Sorgente, A., Iannello, P., \& Antonietti, A. (2019, July 9). The Role of Spirituality and Religiosity in Subjective Well-Being of Individuals With Different Religious Status, Frontiers in Psychology. https://doi.org/10.3389/fpsyg.2019.01525

Ward, P. A. (1990). Ethics and Recent Literary Theory: The Reader as Moral Agent. Religion \& Literature, 22(2/3), 21-31. www.jstor.org/stable/40059446.

Watson, E. (2014, September 20). Gender equality is your issue too. UN Women. https://www.unwomen.org/en/news/stories/2014/9/emma-watson-gender-equality-is-your-issue-too 